\title{
Business contribution to the Sustainable Development Agenda: Organizational factors related to early adoption of SDG reporting
}

Rosati, Francesco; Faria, Lourenço Galvão Diniz

Published in:

Corporate Social Responsibility and Environmental Management

Link to article, DOI:

$10.1002 /$ csr. 1705

Publication date:

2019

Document Version

Peer reviewed version

Link back to DTU Orbit

Citation (APA):

Rosati, F., \& Faria, L. G. D. (2019). Business contribution to the Sustainable Development Agenda:

Organizational factors related to early adoption of SDG reporting. Corporate Social Responsibility and Environmental Management, 26(3), 588-597. https://doi.org/10.1002/csr.1705

\section{General rights}

Copyright and moral rights for the publications made accessible in the public portal are retained by the authors and/or other copyright owners and it is a condition of accessing publications that users recognise and abide by the legal requirements associated with these rights.

- Users may download and print one copy of any publication from the public portal for the purpose of private study or research.

- You may not further distribute the material or use it for any profit-making activity or commercial gain

- You may freely distribute the URL identifying the publication in the public portal 


\title{
Business contribution to the Sustainable Development Agenda: Organizational factors related to early adoption of SDG reporting
}

\author{
Francesco Rosati (frro@dtu.dk) ${ }^{1}$ \\ Department of Management Engineering, Technical University of Denmark, Kgs. Lyngby, Denmark \\ Lourenço Galvão Diniz Faria (loufa@dtu.dk) \\ Department of Management Engineering, Technical University of Denmark, Kgs. Lyngby, Denmark
}

\begin{abstract}
Business can play a critical role in the achievement of the Sustainable Development Goals (SDGs). Contextually, business reporting on the SDGs can support organizations in planning, implementing, measuring, and communicating their SDG efforts. This study investigates the relationship between early adoption of SDG reporting and a series of organizational factors by combining data from two databasesprovided by the Global Reporting Initiative and Orbis - to identify the organizations that addressed the SDGs in their sustainability reports and their respective structural characteristics. The study, using a logit model based on data from 408 organizations worldwide, indicates that early adoption of SDG reporting is related to a larger size, a higher level of intangible assets, a higher commitment to sustainability frameworks and external assurance, a higher share of female directors, and a younger board of directors. The study contributes to the academic and practical understanding of factors related to the decision to engage early in new sustainability frameworks and practices.
\end{abstract}

\section{Keywords}

Sustainable Development Goals (SDGs); corporate sustainability reporting; organizational factors; Global Reporting Initiative.

\footnotetext{
${ }^{1}$ Corresponding Author: Francesco Rosati (frro@dtu.dk), Department of Management Engineering, Technical
} University of Denmark, Centrifugevej, Building 372, room 207, DK-2800 Lyngby, Tel: +45 45256021. 


\section{Introduction}

A great challenge in the implementation of the sustainable development agenda is changing business attitudes towards new sustainability practices, technologies and business models (Sachs, 2012; Welford, 1998). The adoption of more sustainable practices, technologies and business models might be motivated by distinct factors, such as competitive opportunities and threats, compliance with regulations, and pressure from external and internal stakeholders (Belal, 2002; Calabrese et al., 2013; Elliot, 2013). Finding elements that explain the adoption of sustainability practices has been the target of many different theoretical approaches, including legitimacy, stakeholder and signaling theories (Hahn and Kühnen, 2013). In particular, legitimacy theory suggests that organizations need to obtain legitimacy from society to be able to successfully operate in their respective business environments (Deegan, 2002). To be accepted in the society they operate in, organizations need to act responsibly and sustainably in collaboration with their internal and external stakeholders. Coherently, stakeholder theory proposes that organizations willing to successfully conduct their business need to take into account their stakeholders’ perspectives and expectations (Freeman, 1994).

Corporate sustainability reporting can be of great help in addressing societal and stakeholder demands and, consequently, obtaining legitimacy. In this sense, the elements that drive sustainability reporting are most likely related to reducing information asymmetries and increasing reputation among stakeholders (Jizi, 2017). As suggested by signaling theory, signaling social and environmental commitment to stakeholders can help organizations secure competitive positions and even create new competitive advantages (Fracarolli Nunes and Lee Park, 2017; Milne and Gray, 2013). To achieve these benefits, organizations strategically choose the elements that are present in their sustainability reports, which may signal the degree of their sustainability commitment to stakeholders (Belal, 2002; Calabrese et al., 2015).

One of the aspects through which organizations might differentiate themselves in relation to their sustainability reporting is the adoption of emerging sustainability concepts and frameworks (Jensen and Berg, 2012), such as those currently represented by the Sustainable Development Goals (SDGs) (United Nations General Assembly, 2015). The SDGs were presented as part of the 2030 Agenda for Sustainable Development in 2015, when the member states of the United Nations agreed upon the creation of a global agenda for sustainable development based on 169 targets grouped into 17 SDGs. The Sustainable Development Goals tackle a wide spectrum of issues relevant to sustainable development such as poverty, health, education, climate change, and environmental degradation. According to the 2030 
Agenda for Sustainable Development, business plays a critical role in the achievement of these goals (Agarwal et al., 2017; Rosati and Faria, 2018). The United Nations Global Compact (UNGC) and the Global Reporting Initiative (GRI) have recently set up a new joint initiative (i.e., Reporting on the SDGs, Global Reporting Initiative, 2018; United Nations Global Compact, 2018) aimed at enabling “businesses to incorporate SDG reporting into their existing processes, empowering them to act and make the achievements of the SDGs a reality” (United Nations Global Compact, 2018).

When investigating the adoption of new sustainability practices and guidelines, most of the literature tends to focus on the effects of regulatory instruments and stakeholder pressure (Kolk, 2010; Spence et al., 2010), while the influence of internal organizational factors, such as organizational structural characteristics, governance, and performance, is often considered a black box (Faria and Andersen, 2017a; Lozano, 2015; OECD, 2011). In this study, we aim to fill this gap by investigating the organizational factors that may be related to early adoption of new sustainability reporting practices (i.e., SDG reporting), as a reaction to new stakeholder pressures and as a means for improving corporate legitimacy and signaling sustainability commitment (Hahn and Kühnen, 2013; Ortas et al., 2015). In doing so, we intend to contribute to the bodies of literature on stakeholder theory, legitimacy theory and signaling theory by providing a novel study that identifies the profile of the organizations that are more likely to experience an agile adoption of emerging sustainability practices.

Previous studies using stakeholder, legitimacy, and/or signaling theories show that there may be different organizational factors influencing corporate sustainability reporting (see also Ali et al., 2017; Hahn and Kühnen, 2013), such as: organization size (e.g., Patten, 2002; Reverte, 2009), economic and financial performance (e.g., Sotorrío and Sánchez, 2010; Tagesson et al., 2009), and social and environmental commitment (e.g., O’Donovan, 2002). Accordingly, in this study, we aim to test the relationships between these factors and early adoption of SDG reporting. Moreover, since previous research has called for new contributions on the influence of governance issues on corporate sustainability reporting practices (Hahn and Kühnen, 2013), this study also aspires to shed light on the relationship that exists between SDG reporting and corporate governance attributes.

Therefore, in this study, we discuss and test a series of hypotheses, grouped into three dimensions, capturing the above-mentioned structural characteristics of organizations: 1) organization size, economic performance, and intangibility; 2) sustainability commitment and external assurance; and 3) corporate governance attributes. We combine data from two databases, GRI and Orbis, in order to evaluate statistically the patterns in the characteristics of the organizations that address the SDGs in their sustainability reports. 
The following section presents the research hypotheses. Section 3 presents the research method and dataset, and Sections 4 and 5 provide the results of the study and their discussion. The final section presents a summary of the study conclusions, limitations and recommendations for future studies (Section 6).

\section{Research hypotheses}

\subsection{Organization size, economic performance, and intangibility}

The structural characteristics of an organization are cited in the literature as affecting sustainability reporting. The literature often discusses the influence of such characteristics by pointing out that a certain level of resources is required for the organization to commit to sustainability issues. Here, we discuss three structural dimensions: size, economic performance, and intangibility (Figure 1).

The size of an organization may affect its willingness to report the SDGs, since large organizations might be more prone to integrate environmental practices than smaller ones, due to a number of reasons. First, larger organizations have access to more resources, in terms of both scale and scope, which can be crucial for funding the investments necessary to commit to the SDGs and overcoming the risks of inherent in changing established organizational and technological competences and routines (Aragón-Correa et al., 2008; Udayasankar, 2008). Large organizations also have increased exposure compared to smaller ones; they gather more attention from the public and are more vulnerable to adverse reactions and public opinion (Artiach et al., 2010; Shabana et al., 2016). Therefore, elements such as reputation, image, and stakeholder relationships play a larger role, making larger organizations more eager to avoid environmental scandals and focus more on competitors' sustainability strategies (Chen et al., 2006; Saiia et al, 2003; Miles, 1987). Thus, we would like to test if organization size is related to early adoption of SDG reporting:

$H_{1 a}$ : Larger organizations are more likely to address the SDGs in their sustainability reports.

This study also aims to test whether organizations with stronger economic performance are more likely to address the SDGs in their sustainability report. According to Ullmann (1985), higher levels of economic performance are related to a willingness to devote resources to social and environmental demands. As for size, higher levels of profitability provide organizations with further resources and 
flexibility, which might encourage them to show their willingness to commit to sustainability issues, such as the ones represented by the SDGs (Kent and Monem, 2008). Economic performance, however, is not directly related to the size, as even very small organizations might experience high profitability levels, and therefore should be tested separately. Thus, our hypothesis is that:

$H_{1 b}$ : Organizations with higher levels of economic performance are more likely to address the SDGs in their sustainability reports.

Another structural characteristic that might affect the decision to address the SDGs is the presence of intangible assets that might provide competitive advantages, putting the organization in a better position to commit resources towards sustainable practices. Intangible resources are “invisible assets”, not subject to any valuation that increases the market value of the organization beyond their tangible asset value.

The Tobin's $q$ is considered a reliable indicator of intangible assets and represents the difference between the organization's market value and the replacement cost of its tangible assets (Villalonga, 2004). It is usually referred to as an indicator of superior technical and/or organizational competences (Teece et al., 1994) that are tacit and hard to codify by nature, thus difficult to acquire, develop, and be replicated internally and by other organizations. This leads to sustained competitive advantages for the organizations that possess these competences (Itami and Roehl, 1991; Nelson, 1991).

As for size and economic performance, organizations with superior competences might find themselves in a better position to commit to sustainability goals, either because they possess competences that are useful to achieve sustainability goals, or because they enjoy a better position on the market due to the competitive advantages generated by those superior competences. Also, organizations with superior competences are often in the forefront of the technological race, which for a number of sectors is increasingly linked with the development of green technologies (Faria and Andersen, 2017). On the other hand, a pro-active attitude towards sustainability may lead to the development of new intangible assets, including reputation or new technological competences associated with sustainable products and processes (Russo and Fouts, 1997; Shrivastava, 1995).

Accordingly, Konar and Cohen (2001) find a positive significant relationship between environmental performance and intangibility levels, and Prado-Lorenzo et al. (2009) indicate a positive relationship between the extent of reporting and intangibility levels. Summarizing this, our third hypothesis tests the following: 
$H_{1 c}$ : Organizations with higher intangibility levels are more likely to address the SDGs in their sustainability reports.

Insert Figure 1 about here

\subsection{Sustainability commitment and external assurance}

Our fourth hypothesis concerns the relationship between being engaged in voluntary sustainability programs and external assurance and addressing the SDGs in sustainability reports. Voluntary sustainability programs include, among others, the Global Reporting Initiative (GRI), the Carbon Disclosure Project (CDP), the United Nations' Global Compact (UNGC), and the International Finance Corporation's Sustainability Framework.

It is argued in the literature that the implementation of environmental management systems and sustainability practices may lead to additional search processes for environmental, technological, and organizational innovation (Wagner, 2008). The adoption of voluntary practices and frameworks is, above all, an ethical choice that depends on the organization's strategy and mindset. Therefore, we argue that the commitment to voluntary sustainability disclosure programs may be an indicator that organizations already possess the skills and mindset necessary to address the SDGs in their sustainability reports. Our fourth hypothesis is thus:

$\mathrm{H}_{2 a}$ : Organizations committed to voluntary sustainability disclosure programs and frameworks are more likely to address the SDGs in their reports.

In addition to voluntary initiatives, many organizations adopt external verification of their respective sustainability management processes to increase the robustness, accuracy, and trustworthiness of the information disclosed in their reports (Global Reporting Initiative, 2013; Simnett et al., 2009). The external assurance is provided by independent organizations, such as accountancy, engineering, or sustainability service companies, and may include validation through assurance standards such as the AccountAbility AA1000 Assurance Standard (AA1000AS), the International Standard on Assurance Engagements (ISAE) 3000, and several other national and international frameworks and guidelines. It is argued that external validation is an indicator of legitimacy and commitment to sustainability reporting 
(Schaltegger and Wagner, 2011). Therefore, regarding hypothesis $H_{2 b}$, we posit that organizations adopting these practices already present a strategic orientation that is compatible with early commitment to the SDGs:

$\mathrm{H}_{2 b}$ : Organizations adopting external assurance of their sustainability management processes are more likely to address the SDGs in their sustainability reports.

\subsection{Corporate governance attributes}

The board of directors is responsible for developing the strategy of the organization, which includes setting its sustainability agenda and allocating resources towards sustainable practices and technologies (Jizi, 2017). The composition of these boards, including the different characteristics and backgrounds of their members, may influence their decisions to report sustainability indicators and set sustainability commitments (Cucari et al., 2018; Frias-Aceituno et al., 2013; Kaymak and Bektas, 2017; Post et al., 2011).

Several studies indicate that a higher proportion of female board directors is associated with a higher environmental and social involvement and a higher probability of reporting on sustainability issues (see, Fernandez-Feijoo et al., 2012; Fernandez-Feijoo et al., 2014; Johnson and Greening, 1999; Srinidhi, 2011; Williams, 2003). It is argued that gender diversity among the members raises an organization's effectiveness in developing stronger connections with stakeholders and representing their needs and diversity (Adams and Ferreira, 2009; Frias-Aceituno et al., 2013). Accordingly, Glass et al. (2016) find that gender diversity in leadership teams raises their effectiveness in pursuing environmentally friendly strategies. Indeed, "women on boards of directors bring new perspectives to the board and encourage the establishment, implementation and reporting on energy efficiency, green building and climate change policies to enhance shareholders' social welfare and to mirror firms’ good citizenship” (Jizi, 2017, p. 642). Fernandez-Feijoo et al. (2012) find that a higher proportion of women on boards can be positively related to a higher quality of CSR disclosure, by including more information on organizations' CSR strategies and assurance statements. Post et al. (2011) also find a positive and significant correlation between having three or more female directors on a board and higher ratings of corporate environmental, social, and governance actions. Conversely, Cucari et al. (2018) show that gender diversity on boards is negatively correlated with CSR disclosure, and Khan (2010) does not find any significant effect. However, the general opinion in the literature is that women demand higher levels of sustainability (Calabrese et al., 2016; Lämsä et al., 2008; Rosati et al., 2018) and are more prone to use moral reasoning 
and to behave ethically, especially in situations where behavior is not delineated by any clear organizational policy (Smith and Rogers, 2000). Therefore, we posit that:

$H_{3 a}$ : Organizations that contain a higher proportion of women on the board of directors are more likely to address the SDGs in their sustainability reports.

Moreover, this study aims to test if the average age of the members is related to the decision to address the SDGs. The literature on this theme presents contrasting evidence (Cucari et al., 2018; Post et al., 2011). On one hand, it is argued that older individuals, similar to female members, present a higher moral reasoning and environmental consciousness than younger ones (Forte, 2004). However, since the mainstream discussion on sustainable development is quite recent (World Commission on Environment and Development, 1987), it is argued that younger individuals are exposed earlier in life to sustainable development, and possess more knowledge about it (Diamantopoulos et al., 2003). Accordingly, Klineberg et al. (1998) found that younger individuals are more concerned about environmental quality issues and show more commitment to environmental protection. In this sense, our last hypothesis is that:

$H_{3 b}$ : Organizations with a younger board of directors (on average) are more likely to address the SDGs in their sustainability reports.

\section{Dataset and method}

To test the hypotheses presented, we combined data from two sources - the Global Reporting Initiative (GRI) database and the Orbis database, from Bureau van Dijk. ${ }^{2}$ First, from the GRI database, we extracted data about the presence of SDGs in sustainability reports published in 2016. More specifically, the GRI database indicates whether organizations addressed the SDGs in their sustainability reports. This data was available only for organizations following the GRI guidelines (e.g. G4). This variable was used as the dependent variable in our model. Furthermore, through the GRI database, we extracted data containing the organizations' names, countries of origin, sectors, and relationships with a number of voluntary sustainability frameworks and guidelines (e.g. the United Nations’ Global Compact (UNGC), the Carbon Disclosure Project (CDP), the International Finance Corporation's Sustainability

\footnotetext{
${ }^{2}$ Available at https://www.bvdinfo.com/en-gb/our-products/data/international/orbis.
} 
Framework (IFC), the ISO 26000:2010 (ISO)), as well as information about the adoption of external assurance on their sustainability reports and practices (EXAS) and the application of the AccountAbility AA1000 Assurance Standard. These variables were used to represent the hypotheses related to sustainability commitment and external assurance $\left(H_{2 a}\right.$ and $\left.H_{2 b}\right)$.

From the GRI database, we originally obtained data on 2,413 sustainability reports published in 2016 by 2,413 different organizations. The names of the 2,413 organizations were then matched with entries in the second database, Orbis, to gather data on economic and financial performance, corporate governance, and other structural attributes of the organizations, representing the remaining set of hypotheses $\left(H_{1 a}, H_{1 b}, H_{1 c}, H_{3 a}\right.$ and $\left.H_{3 b}\right)$. After combining the two databases, a sample of 408 observations with full data was obtained, which formed the basis for our analysis. The characteristics of the sample population, by region, country, and sector are presented in Table 1 . The variables considered in the study are summarized in Table 2.

Insert Table 1 about here

Insert Table 2 about here

We estimate a model where we assumed that the probability of an organization addressing the SDGs in its sustainability report is related to the factors discussed beforehand (commitment to sustainability frameworks and external assurance, corporate governance, organization size, unique technological and organizational competences, and economic performance). Since our dependent variable can assume only two states (yes/no), a binary probability model (logit) was chosen as the analytical tool to run the regressions. Similar models have been adopted in several analyses of sustainability reporting and assurance (Martínez-Ferrero and García-Sánchez, 2017; Peters and Romi, 2014; Simnett et al., 2009). The basic model can be summarized as follows:

$$
\mathrm{SDG}=\left\{\begin{array}{l}
1 \text { if } \beta_{0}+\beta_{1}(\text { size })+\beta_{2}(\text { ecperf })+\beta_{3}(\text { intang })+\beta_{4}(\text { sustcomm })+\beta_{5}(\text { corpgov })+\varepsilon \\
0 \text { otherwise }
\end{array}\right.
$$

Where: 
- Several proxies of size were selected to represent the size and importance of the organizations: operating revenue (OPREV), number of employees (EMPL), total asset value (ASSET), market capitalization (MCAP), sales revenue (SALES), taxation (TAX), and EBIDTA (earnings before interest, depreciation, taxes, and amortization). The indicators were grouped into one variable (SIZE) through principal component factor analysis, to eliminate multicollinearity. Exploratory principal components analysis, with varimax rotation of these items, showed that they formed only one factor with eigenvalue $=5.41$ and Cronbach's alpha $=0.82$.

- Two variables were used to represent economic performance (ecperf): PM (profit margins) and $R O E$ (return on equity).

- The Tobin’s $q$ (TOBQ) was used to represent the organizations' intangibility levels (intang).

- Sustcomm (sustainability commitment and external assurance) consists of a number of dummy variables representing the commitment to additional sustainability frameworks (UNGC, CDP, IFC, ISO) and external assurance (EXAS, AA).

- The variables FEM (percentage of women on the board of directors) and AGE (average age, expressed as years, of the board of directors) are two of the most important corporate governance attributes (corpgov) mentioned in the literature and were used to represent the diversity in the board of directors.

Finally, when running the model, we controlled for the effects of country and sector for each observation.

\section{Results}

Only 67 out of the 408 organizations included in the sample (16\%) addressed the SDGs in the reports published in 2016. The results for the statistical models are presented in Table 3. We ran five logit models to ensure that the coefficients were consistent.

A larger size was found to be a characteristic of the organizations that reported on the SDGs, according to the results of our models. The factor variable SIZE was positive and significant in all models tested. Based on that, we accept hypothesis $H_{1 a}$. The economic performance variables were of little significance for the model. Surprisingly, the return on equity (ROE) was found to have a weak negative relationship with SDG reporting. We, therefore, reject hypothesis $H_{1 b}$, which posits that organizations with higher levels of economic performance are more likely to address the SDGs in their sustainability reports. It is interesting to note that organizations with higher intangibility levels were generally more 
likely to address the SDGs, even though such a relationship was not significant when we controlled for country and sector (Model 5). Based on the overall results, we accept hypothesis $H_{1 c}$ and suggest that this relationship might be due to sector or country specificities rather than the possession of superior competences per se.

Regarding the relationship between sustainability commitment and external assurance and the probability of early adoption of SDG reporting, commitments to the UNGC and CDP were the only variables with a highly significant coefficient in all models. The presence of external assurance was only weakly significant but with a positive coefficient. Based on the results, we accept hypotheses $H_{2 a}$ and $H_{2 b}$. However, we emphasize that not all the sustainability frameworks examined here are significantly related to early adoption of SDG reporting.

Among the corporate governance factors, the results suggest a positive, albeit weakly significant relationship between reporting on the SDGs and having a higher percentage of women on the directors' board (variable FEM). Second, the variable $A G E$ was reported to be significant, with a negative signal, indicating that older boards of directors (on average) are negatively related to early adoption of SDG reporting. Thus, we accept hypotheses $H_{3 a}$ and $H_{3 b}$, stating that organizations with boards of directors containing a higher proportion of women and younger members (on average) are more likely to address the SDGs in their sustainability reports.

Insert Table 3 about here

\section{Discussion}

In this section, we discuss our findings in relation to previous studies on corporate sustainability reporting to identify the organizational factors that are related to a more agile adoption of emerging corporate sustainability reporting practices (i.e., SDG reporting), driven by new stakeholder pressures and new expectations in terms of corporate legitimacy and sustainability signals (Hahn and Kühnen, 2013; Ortas et al., 2015). In particular, we discuss the results obtained in the three dimensions investigated in the study, namely: 1) organization size, economic performance, and intangibility; 2) sustainability commitment and external assurance; and 3) corporate governance attributes. 
According to the results of our models, organization size can also play an important role in SDG reporting. The factor variable SIZE was positive and significant in all models tested, corroborating previous studies in the corporate sustainability literature, which found that larger organizations show higher performance in reporting their sustainability management issues and performance indicators (for a literature review, see Hahn and Kühnen, 2013). This result might be due to the fact that organizations with more resources have a better awareness of sustainability issues, having more time and money to allocate to sustainability practices (Hutchinson and Chaston, 1994). Larger organizations are also more concerned with their public image since they attract greater attention from their stakeholders (Artiach et al., 2010). Thus, this can lead to larger organizations engaging in emerging sustainability discussions earlier than smaller ones.

Our findings also show that higher intangibility levels seem to be generally related to the decision to address the SDGs in the sustainability report. This relationship might be due to the link between superior competences (e.g. technological, marketing, brand) and better conditions for committing to sustainability goals, which might give these organizations a more proactive attitude. However, this relationship was not significant when we controlled for country and sector. Thus, this relationship might be due to sector or country specificities, rather than the possession of superior competences per se. Finally, the economic performance variables were of little significance for the model. Surprisingly, the ROE was found to have a weak negative relationship with SDG reporting. The literature offers mixed findings with respect to the influence of this variable in corporate sustainability reporting. Li et al., (2013), for instance, observed a negative relationship between ROE and CSR disclosure, which is in line with our findings, while Khan (2010) and Sharif and Rashid (2014) reported a positive one. Further research might reveal additional factors influencing the relationship between economic performance and SDG reporting.

Regarding the relationship between sustainability commitment and external assurance and the probability of addressing the SDGs in the sustainability report, our findings suggest that only commitments to the UNGC and CDP are significantly related to SDG reporting. This is not surprising, given that both frameworks suggest the implementation of SDGs in business. ${ }^{3}$ The result suggests the importance of interconnectivity among sustainability frameworks. In this sense, engagement in one framework is likely to function as a gateway to the adoption of future ones, if there is a degree of institutional relatedness among them. The presence of external assurance is only weakly significant but with a positive coefficient. This indicates that a stronger external validation can be associated with a higher probability of addressing the SDGs in the sustainability report.

\footnotetext{
${ }^{3}$ See for instance https://www.cdp.net/sdgs and https://www.unglobalcompact.org/library/3101
} 
Among the corporate governance factors, our results suggest a positive, albeit weakly significant, relationship between SDG reporting and the percentage of women on the directors' board. This is in line with previous studies in the corporate sustainability literature, which show that a higher percentage of women on the board of directors might positively influence the incorporation of new sustainability issues and perspectives in business (Johnson and Greening, 1999; Post et al. 2011; Williams, 2003, Gul et al., 2011; Srinidhi et al., 2011). Second, the results suggest that organizations with older boards of directors (on average) are less likely to address the SDGs. According to Post et al. (2011), this relationship might be due to the greater exposure that younger directors have to environmental issues, or their willingness to include emerging frameworks within the organization, since younger individuals tend to be more connected to and aware of novelty.

\section{Conclusion}

In this study, we investigated the relationship between the decision on early adoption of SDG reporting and three dimensions capturing structural elements of the organizations, namely: 1) organization size, economic performance, and intangibility; 2) sustainability commitment and external assurance; and 3) corporate governance attributes. The study contributed to the academic debate by identifying the relationship between certain organizational characteristics and the adoption of emerging practices in sustainability reporting. The study identified the profile of the organizations that are more likely to experience a more agile adoption of new sustainability reporting frameworks, and thus quickly respond to new stakeholder pressures and the need to improve corporate legitimacy and provide new sustainability signals. In so doing, such an investigation can inform the literature on stakeholder theory, legitimacy theory, and signaling theory, focusing on the organizational characteristics related to a quicker adoption of emerging sustainability practices.

In particular, the results of the statistical analysis suggest that the organizations that addressed the SDGs in the sustainability report belong to a group with specific characteristics. First, they are mostly large organizations, with additional resources and more sensitive brands that they are willing to protect by demonstrating early engagement in emerging sustainability frameworks. Second, they also have higher levels of intangible assets; therefore, more competences that can be used to target the SDGs, even though this relationship seemed to be due to their sector and country of origin. Third, they are more likely to adopt external assurance and to follow other related sustainability frameworks, such as the UNGC and 
the CDP. Fourth, their boards of directors are composed of younger individuals and have a higher proportion of female members.

From a practical perspective, the results of this study contribute to understanding the characteristics that are related to the decision to engage early in sustainability frameworks, both for policymakers to target leaders and laggards, and for practitioners to elaborate different strategies for organizations with different profiles.

A drawback of the study is that we did not include other variables that might also affect the willingness to address the SDGs, such as public exposure, and a more detailed analysis of sector and country of origin. Moreover, all organizations in the sample committed to the most recent GRI guidelines, which may represent a bias. Thus, further research might focus on non-GRI reporting organizations, to test the results of this study and reveal additional factors related to SDG reporting.

\section{References}

Adams RB, Ferreira D. 2009. Women in the boardroom and their impact on governance and performance. Journal of Financial Economics 94(2): 291-309.

Agarwal N, Gneiting U, Mhlanga R. 2017. Raising the Bar: Rethinking the role of business in the Sustainable Development Goals. OXFAM.

Ali W, Frynas JG, Mahmood Z. 2017. Determinants of Corporate Social Responsibility (CSR) Disclosure in Developed and Developing Countries: A Literature Review. Corporate Social Responsibility and Environmental Management 24(4): 273-294. DOI: 10.1002/csr.1410.

Aragón-Correa JA, Hurtado-Torres N, Sharma S, García-Morales VJ. 2008. Environmental strategy and performance in small firms: A resource-based perspective. Journal of Environmental Management 86(1): 88-103. DOI: 10.1016/j.jenvman.2006.11.022.

Artiach T, Lee D, Nelson D, Walker J. 2010. The determinants of corporate sustainability performance. Accounting and Finance 50(1): 31-51. DOI: 10.1111/j.1467-629X.2009.00315.x.

Belal AR. 2002. Stakeholder accountability or stakeholder management: a review of UK firms’ social and ethical accounting, auditing and reporting (SEAAR) practices. Corporate Social Responsibility and Environmental Management 9(1): 8-25. DOI: 10.1002/csr.5.

Calabrese A, Costa R, Menichini T, Rosati F, Sanfelice G. 2013. Turning Corporate Social Responsibility-driven Opportunities in Competitive Advantages: a Two-dimensional Model. Knowledge and Process Management 20(1): 50-58. DOI: 10.1002/kpm.1401. 
Calabrese A, Costa R, Rosati F. 2015. A feedback-based model for CSR assessment and materiality analysis. Accounting Forum. Elsevier Ltd 39(4): 312-327. DOI: 10.1016/j.accfor.2015.06.002.

Calabrese A, Costa R, Rosati F. 2016. Gender differences in customer expectations and perceptions of corporate social responsibility. Journal of Cleaner Production 116: 135-149. DOI: 10.1016/j.jclepro.2015.12.100.

Chen Y-S, Lai S-B, Wen C-T. 2006. The Influence of Green Innovation Performance on Corporate Advantage in Taiwan. Journal of Business Ethics 67(4): 331-339. DOI: 10.1007/s10551-0069025-5.

Cucari N, Falco SE De, Orlando B. 2018. Diversity of Board of Directors and Environmental Social Governance: Evidence from Italian Listed Companies. Corporate Social Responsibility and Environmental Management 25: 250-266. DOI: 10.1002/csr.1452.

Deegan C. 2002. Introduction: The legitimising effect of social and environmental disclosures - a theoretical foundation. Accounting, Auditing \& Accountability Journal 15(3): 282-311. DOI: 10.1108/09513570210435852.

Diamantopoulos A, Schlegelmilch BB, Sinkovics RR, Bohlen GM. 2003. Can socio-demographics still play a role in profiling green consumers? A review of the evidence and an empirical investigation. Journal of Business Research 56(6): 465-480. DOI: 10.1016/S0148-2963(01)00241-7.

Elliot S. 2013. A Transdisciplinary Exploratory Model of Corporate Responses to the Challenges of Environmental Sustainability. Business Strategy and the Environment 22(4): 269-282. DOI: 10.1002/bse.1774.

Faria LGD, Andersen MM. 2017a. Sectoral patterns versus firm-level heterogeneity - The dynamics of eco-innovation strategies in the automotive sector. Technological Forecasting and Social Change 117: 266-281. DOI: 10.1016/J.TECHFORE.2016.11.018.

Faria LGD, Andersen MM. 2017b. Sectoral dynamics and technological convergence: an evolutionary analysis of eco-innovation in the automotive sector. Industry and Innovation 24(8): 837-857. DOI: 10.1080/13662716.2017.1319801.

Fernandez-Feijoo B, Romera S, Ruiz S. 2012. Does board gender composition affect corporate social responsibility reporting? International Journal of Business and Social Science 3(1): 31-39.

Fernandez-Feijoo B, Romero S, Ruiz-Blanco S. 2014. Women on boards: Do they affect sustainability reporting? Corporate Social Responsibility and Environmental Management 21(6): 351-364.

DOI: 10.1002/csr.1329.

Forte A. 2004. Antecedents of managers moral reasoning. Journal of Business Ethics 51(4): 315-347. Fracarolli Nunes M, Lee Park C. 2017. Self-claimed sustainability: Building social and environmental 
reputations with words. Sustainable Production and Consumption 11: 46-57. DOI: 10.1016/J.SPC.2016.04.002.

Freeman RE. 1994. The politics of stakeholder theory: Some future directions. Business ethics quarterly. JSTOR : 409-421.

Frias-Aceituno J V., Rodriguez-Ariza L, Garcia-Sanchez IM. 2013. The role of the board in the dissemination of integrated corporate social reporting. Corporate Social Responsibility and Environmental Management 20(4): 219-233. DOI: 10.1002/csr.1294.

Glass C, Cook A, Ingersoll AR. 2016. Do Women Leaders Promote Sustainability? Analyzing the Effect of Corporate Governance Composition on Environmental Performance. Business Strategy and the Environment 25(7): 495-511. DOI: 10.1002/bse.1879.

Global Reporting Initiative. 2013. The external assurance of sustainability reporting. Research and Development Series. Amsterdam (The Netherlands). Available at: https://www.globalreporting.org/resourcelibrary/GRI-Assurance.pdf.

Global Reporting Initiative. 2018. Business Reporting on the SDGs. Available at: https://www.globalreporting.org/information/SDGs/Pages/Reporting-on-the-SDGs.aspx [17 January 2018].

Hahn R, Kühnen M. 2013. Determinants of sustainability reporting: a review of results, trends, theory, and opportunities in an expanding field of research. Journal of Cleaner Production 59: 5-21. DOI: 10.1016/J.JCLEPRO.2013.07.005.

Hutchinson A, Chaston I. 1994. Environmental management in Devon and Cornwall's small and medium sized enterprise sector. Business Strategy and the Environment 3(1): 15-22. DOI: 10.1002/bse.3280030102.

Itami H, Roehl TW. 1991. Mobilizing invisible assets. Harvard University Press. Jensen JC, Berg N. 2012. Determinants of Traditional Sustainability Reporting Versus Integrated Reporting. An Institutionalist Approach. Business Strategy and the Environment 21(5): 299-316. DOI: $10.1002 / b s e .740$.

Jizi M. 2017. The influence of board composition on sustainable development disclosure. Business Strategy and the Environment 26: 640-655. DOI: 10.1002/bse.1943.

Johnson RA, Greening DW. 1999. The effects of corporate governance and institutional ownership types on corporate social performance. Academy of Management Journal 42(5): 564-576. DOI: $10.2307 / 256977$.

Kaymak T, Bektas E. 2017. Corporate Social Responsibility and Governance: Information Disclosure in Multinational Corporations. Corporate Social Responsibility and Environmental Management 
24: 555-569. DOI: 10.1002/csr.1428.

Kent P, Monem R. 2008. What drives TBL reporting: good governance or threat to legitimacy? Australian Accounting Review 18(4): 297-309. DOI: 10.1111/j.1835-2561.2008.0036.x.

Khan H-U-Z. 2010. The effect of corporate governance elements on corporate social responsibility (CSR) reporting: Empirical evidence from private commercial banks of Bangladesh. International Journal of Law and Management 52(2): 82-109. DOI: 10.1108/17542431011029406.

Klineberg SL, Mckeever M, Rothenbach B. 1998. Demographic Predictors of Environmental Concern: It Does Make a Difference How It’s Measured. Social Science Quarterly 79(4): 734-753.

Kolk A. 2010. Trajectories of sustainability reporting by MNCs. Journal of World Business 45(4): 367-374. DOI: 10.1016/j.jwb.2009.08.001.

Konar S, Cohen MA. 2001. Does the market value environmental performance? Review of Economics and Statistics 83(2): 281-289. DOI: 10.1162/00346530151143815.

Lämsä A-M, Vehkaperä M, Puttonen T, Pesonen H-L. 2008. Effect of Business Education on Women and Men Students' Attitudes on Corporate Responsibility in Society. Journal of Business Ethics 82(1): 45-58. DOI: 10.1007/s10551-007-9561-7.

Li Q, Luo W, Wang Y, Wu L. 2013. Firm performance, corporate ownership, and corporate social responsibility disclosure in China. Business Ethics: A European Review 22(2): 159-173. DOI: 10.1111/beer.12013.

Lozano R. 2015. A holistic perspective on corporate sustainability drivers. Corporate Social Responsibility and Environmental Management 22(1): 32-44. DOI: 10.1002/csr.1325.

Martínez-Ferrero J, García-Sánchez I-M. 2017. Sustainability assurance and assurance providers: Corporate governance determinants in stakeholder-oriented countries. Journal of Management \& Organization 23(05): 647-670. DOI: 10.1017/jmo.2016.65.

Milne MJ, Gray R. 2013. W(h)ither Ecology? The Triple Bottom Line, the Global Reporting Initiative, and Corporate Sustainability Reporting. Journal of Business Ethics 118(1): 13-29. DOI: 10.1007/s10551-012-1543-8.

Nelson RR. 1991. Why do firms differ, and how does it matter? Strategic Management Journal 12: 6174. DOI: $10.1002 / \mathrm{smj} .4250121006$.

O’Donovan G. 2002. Environmental disclosures in the annual report: Extending the applicability and predictive power of legitimacy theory. Accounting, Auditing \& Accountability Journal 15(3): 344371. DOI: 10.1108/09513570210435870.

OECD. 2011. Towards Green Growth: Monitoring Progress. OECD Green Growth Studies. OECD Publishing. DOI: 10.1787/9789264111356-en. 
Ortas E, Gallego-Alvarez I, Álvarez Etxeberria I. 2015. Financial Factors Influencing the Quality of Corporate Social Responsibility and Environmental Management Disclosure: A Quantile Regression Approach. Corporate Social Responsibility and Environmental Management 22(6): 362-380. DOI: 10.1002/csr.1351.

Patten DM. 2002. The relation between environmental performance and environmental disclosure: a research note. Accounting, Organizations and Society 27: 763-773.

Peters GF, Romi AM. 2014. The association between sustainability governance characteristics and the assurance of corporate sustainability reports. Auditing: A Journal of Practice \& Theory 34(1): 163-198. DOI: 10.2308/ajpt-50849.

Post C, Rahman N, Rubow E. 2011. Green Governance: Boards of Directors’ Composition and Environmental Corporate Social Responsibility. Business \& Society 50(1): 189-223. DOI: 10.1177/0007650310394642.

Prado-Lorenzo J, Rodríguez-Domínguez L, Gallego-Álvarez I, García-Sánchez I-M. 2009. Factors influencing the disclosure of greenhouse gas emissions in companies world-wide. Management Decision 47(7): 1133-1157. DOI: 10.1108/00251740910978340.

Reverte C. 2009. Determinants of corporate social responsibility disclosure ratings by Spanish listed firms. Journal of Business Ethics 88(2): 351-366. DOI: 10.1007/s10551-008-9968-9.

Rosati F, Costa R, Calabrese A, Pedersen ERG. 2018. Employee attitudes towards corporate social responsibility: a study on gender, age and educational level differences. Corporate Social Responsibility and Environmental Management. Available at: http://doi.wiley.com/10.1002/csr.1640.

Rosati F, Faria LGD. 2018. Addressing the Sustainable Development Goals in sustainability reports: the association with institutional factors. Working Paper.

Russo M V, Fouts PA. 1997. A resource-based perspective on corporate environmental performance and profitability. Academy of management Journal 40(3): 534-559. DOI: 10.5465/257052.

Sachs JD. 2012. From millennium development goals to sustainable development goals. The Lancet 379(9832): 2206-2211. DOI: 10.1016/S0140-6736(12)60685-0.

Schaltegger S, Wagner M. 2011. Sustainable entrepreneurship and sustainability innovation: categories and interactions. Business Strategy and the Environment 20(4): 222-237. DOI: 10.1002/bse.682.

Shabana KM, Buchholtz AK, Carroll AB. 2016. The Institutionalization of Corporate Social Responsibility Reporting. Business \& Society 56(8): 1-29. DOI: 10.1177/0007650316628177.

Sharif M, Rashid K. 2014. Corporate governance and corporate social responsibility (CSR) reporting: an empirical evidence from commercial banks (CB) of Pakistan. Quality \& Quantity 48(5): 2501- 
2521. DOI: 10.1007/s11135-013-9903-8.

Shrivastava P. 1995. The role of corporations in achieving ecological sustainability. Academy of management review 20(4): 936-960. DOI: 10.2307/258961.

Simnett R, Vanstraelen A, Chua WF. 2009. Assurance on Sustainability Reports: An International Comparison. The Accounting Review 84(3): 937-967. DOI: 10.2308/accr.2009.84.3.937. Smith A, Rogers V. 2000. Ethics-Related Responses to Specific Situation Vignettes: Evidence of Gender-Based Differences and Occupational Socialization. Journal of Business Ethics 28(1): 7385. DOI: 10.1023/A:1006388923834.

Sotorrío LL, Sánchez JLF. 2010. Corporate social reporting for different audiences: The case of multinational corporations in Spain. Corporate Social Responsibility and Environmental Management 17(5): 272-283. DOI: 10.1002/csr.215.

Spence C, Husillos J, Correa-Ruiz C. 2010. Cargo cult science and the death of politics: A critical review of social and environmental accounting research. Critical Perspectives on Accounting. Elsevier 21(1): 76-89.

Srinidhi B, Gul FA, Tsui J. 2011. Female Directors and Earnings Quality. Contemporary Accounting Research 28(5): 1610-1644. DOI: 10.1111/j.1911-3846.2011.01071.x.

Tagesson T, Blank V, Broberg P, Collin S. 2009. What Explains the Extent and Content of Social and Environmental Disclosures on Corporate Websites: A Study of Social and Environmental Reporting in Swedish Listed Corporations. Corporate Social Responsibility and Environmental Management 16: 352-364. DOI: 10.1002/csr.194.

Teece DJ, Rumelt R, Dosi G, Winter S. 1994. Understanding corporate coherence: Theory and evidence. Journal of Economic Behavior \& Organization 23(1): 1-30. DOI: 10.1016/01672681(94)90094-9.

Udayasankar K. 2008. Corporate social responsibility and firm size. Journal of Business Ethics 83(2): 167-175. DOI: 10.1007/s10551-007-9609-8.

Ullmann AA. 1985. Data in Search of a Theory: A Critical Examination of the Relationships Among Social Performance, Social Disclosure, and Economic Performance of U.S. Firms. Academy of Management Review 10(3): 540-557. DOI: 10.5465/AMR.1985.4278989.

United Nations General Assembly. 2015. Transforming our world: The 2030 agenda for sustainable development. New York. Available at: http://www.un.org/ga/search/view_doc.asp?symbol=A/RES/70/1\&Lang=E.

United Nations Global Compact. 2018. Reporting on the SDGs - Shape the future of corporate reporting on the SDGs. Available at: https://www.unglobalcompact.org/take-action/action/sdg- 
reporting [17 January 2018].

Villalonga B. 2004. Intangible resources, Tobin's q, and sustainability of performance differences. Journal of Economic Behavior and Organization. DOI: 10.1016/j.jebo.2003.07.001.

Wagner M. 2008. Empirical influence of environmental management on innovation: Evidence from Europe. Ecological Economics 66(2-3): 392-402. DOI: 10.1016/j.ecolecon.2007.10.001.

Welford RJ. 1998. Editorial: Corporate environmental management, technology and sustainable development: Postmodern perspectives and the need for a critical research agenda. Business Strategy and the Environment 7(1): 1-12. DOI: 10.1002/(SICI)1099-0836(199802)7:1<1::AIDBSE132>3.0.CO;2-7.

Williams RJ. 2003. Women on Corporate Boards of Directors and their Influence on Corporate Philanthropy. Journal of Business Ethics 42(1): 1-10. DOI: 10.1023/A:1021626024014.

World Commission on Environment and Development. 1987. Report of the World Commission on Environment and Development: Our common future. Oxford paperbacks. Available at: http://www.un-documents.net/our-common-future.pdf. 
Tables

\begin{tabular}{lr}
\hline Region & $\boldsymbol{N}(\%)$ \\
\hline Europe & $212(52.0)$ \\
Northern America & $95(23.3)$ \\
Asia & $78(19.1)$ \\
Latin America and the Caribbean & $10(2.5)$ \\
Oceania & $7(1.7)$ \\
Africa & $6(1.5)$ \\
\hline Country & \\
\hline United States & $90(22.1)$ \\
Sweden & $33(8.1)$ \\
Finland & $32(7.8)$ \\
Germany & $31(7.6)$ \\
India & $20(4.9)$ \\
Japan & $17(4.2)$ \\
Italy & $15(3.7)$ \\
Switzerland & $15(3.7)$ \\
France & $14(3.4)$ \\
China & $13(3.2)$ \\
United Kingdom & $13(3.2)$ \\
Others & $115(28.2)$ \\
\hline Sector & \\
\hline Energy & $25(6.1)$ \\
Chemicals & $24(5.9)$ \\
Energy Utilities & $23(5.6)$ \\
Telecommunications & $23(5.6)$ \\
Real Estate & $22(5.4)$ \\
Food and Beverage Products & $21(5.1)$ \\
Conglomerates & $18(4.4)$ \\
Equipment & $18(4.4)$ \\
Retailers & $17(4.2)$ \\
Technology Hardware & $17(4.2)$ \\
Mining & $408(100.0)$ \\
\hline Others & \\
\hline & \\
\hline
\end{tabular}

Table 1: Characteristics of the sample, by region, country and sector. 


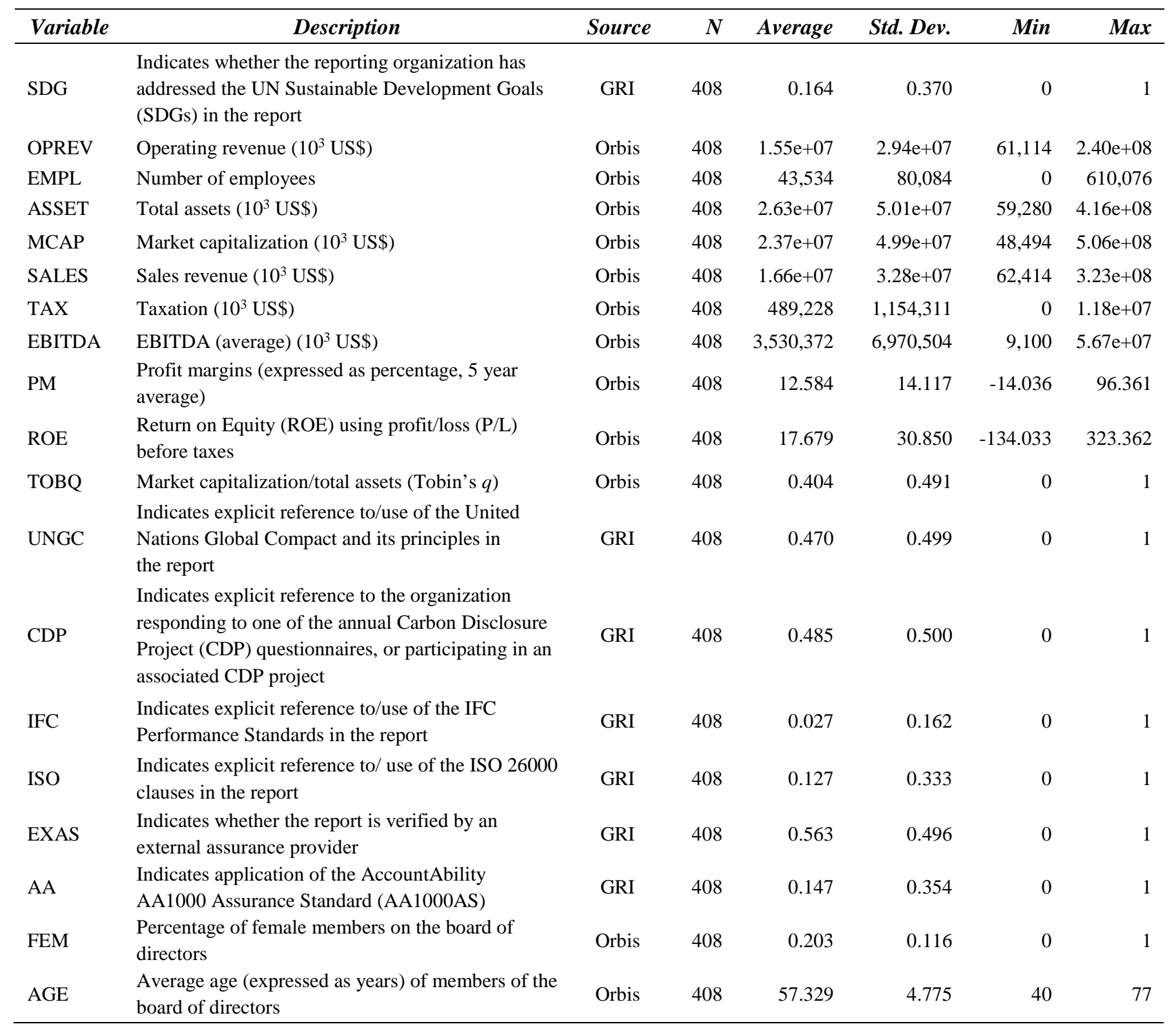

Table 2: Summary of variables.

$N=$ number of observations; std. dev. = standard deviation; min = minimum; max = maximum. 


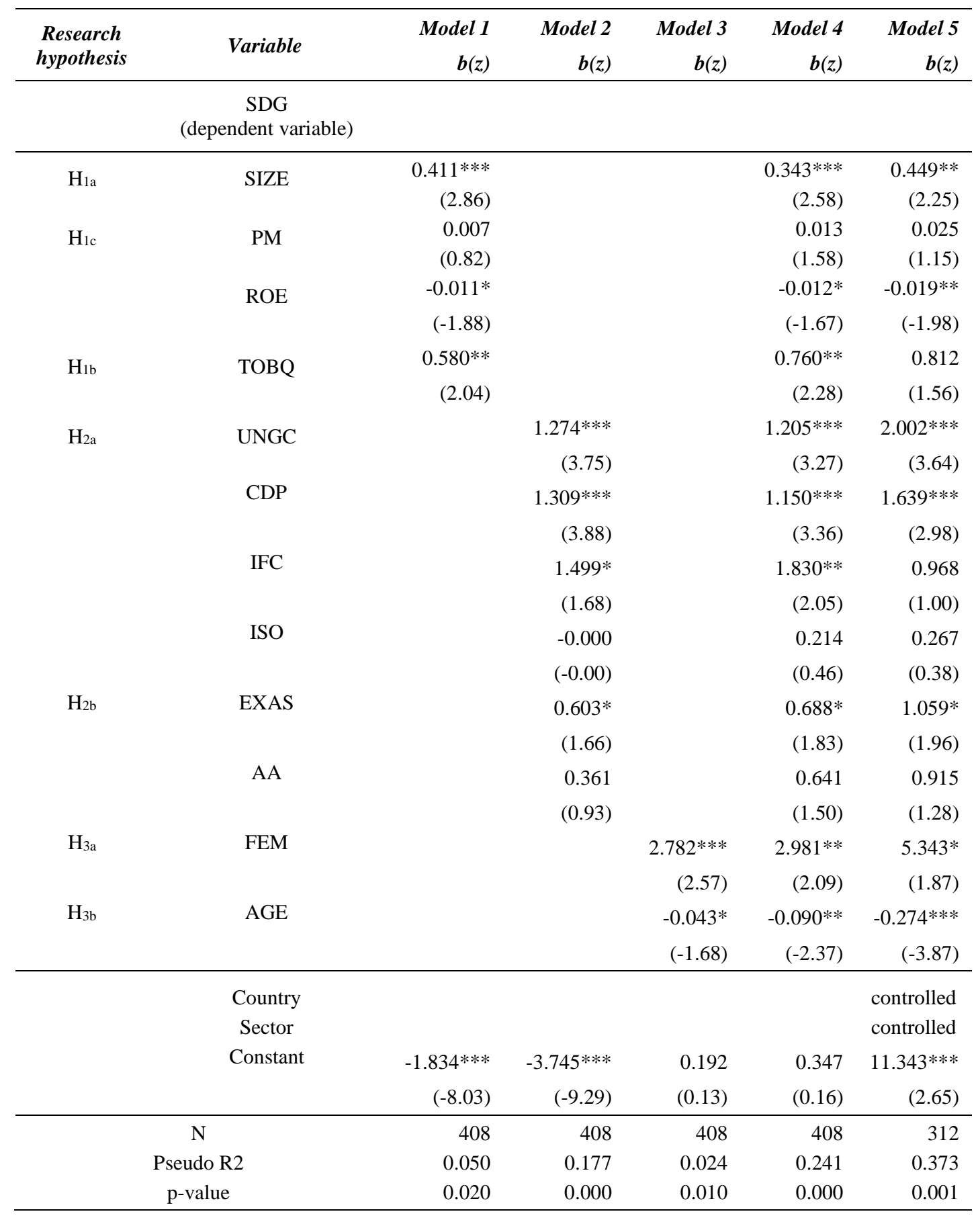

Table 3: Results of the statistical analysis.

$b=$ raw coefficient; $z=z$-value; $N=$ number of observations.

Statistical significance: ${ }^{*}$-value $<0.10,{ }^{* *}$-value $<0.05$, ***p-value $<0.01$. 
Figure 1: Research framework and hypotheses.

1. Organization size, economic performance and intangibility

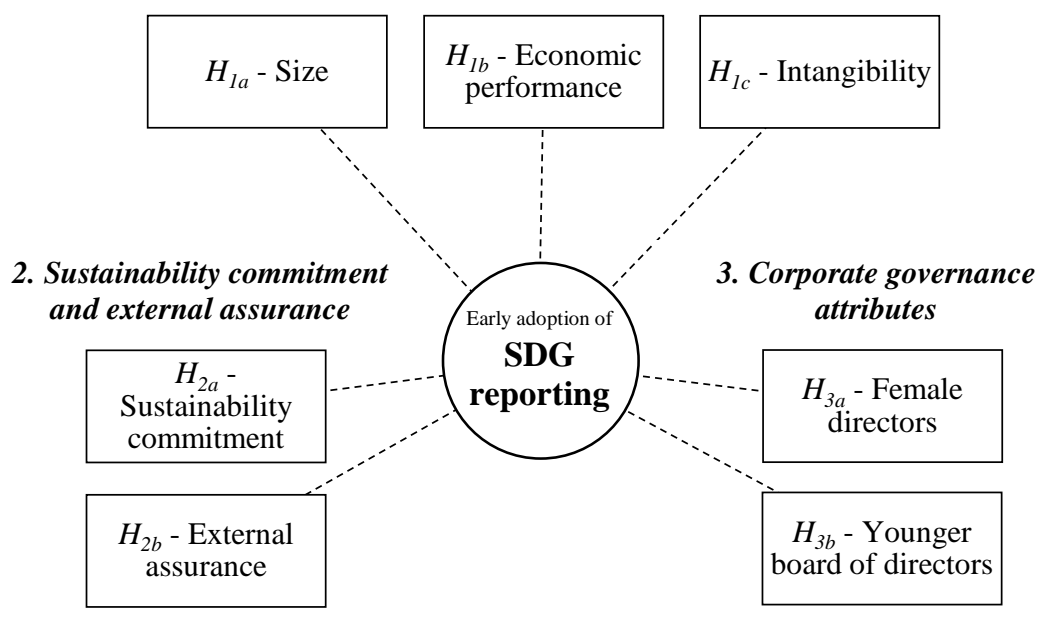

